\title{
インヒビター添加清水中における $\mathrm{Cr}-\mathrm{Mo}$ 鋳鋼の 重畳疲労強度と疲労寿命の推定
}

\author{
三浦 健 蔵* 大井利 継* 田中孝 雄**
}

\author{
Superposed Fatigue Strength and Fatigue Life Estimation of \\ Cr-Mo Cast Steel in Fresh Water with Added Inhibitor \\ by \\ Kenzou MiUrA*, Toshitugu OHI* and Takao TANAKA**
}

Fatigue tests under superposed stress were carried out in air and in fresh water containing sodium nitrite inhibitor $\left(\mathrm{NaNO}_{2}\right)$ at $80^{\circ} \mathrm{C}$ using a relatively large $\mathrm{Cr}-\mathrm{Mo}$ cast steel specimen. The applicability of the equivalent frequency method (ELF method) and the range pair mean method (RPM method) was investigated. The modified Goodman's method (RPM method I) and Yamada's method (RPM method II) were used to evaluate the effect of mean stress on stress amplitude.

The best estimation of fatigue life among those three methods was RPM method II. The ratio of the experimental life, $N$ to the estimated life, $\bar{N}_{e s}$ tended to become low at the high life side for all the three methods. However, when RPM method II was applied on the basis of the completely reversed (stress ratio $R=-1$ ) $S-N$ curve, in which the values under the fatigue limit were corrected, $N / \bar{N}_{e s}$ became within the range of $1 / 3 \leqq N / \bar{N}_{e s} \leqq 5$. It was found that $\mathrm{NaNO}_{2}$ was effective in the prevention of corrosion fatigue. However, the experimental life in fresh water containing $\mathrm{NaNO}_{2}$ at $80^{\circ} \mathrm{C}$ became a little bit lower than that in air. The relation between $\bar{N}_{e s}$ and the cumulative damage, $D$ was represented as follow.

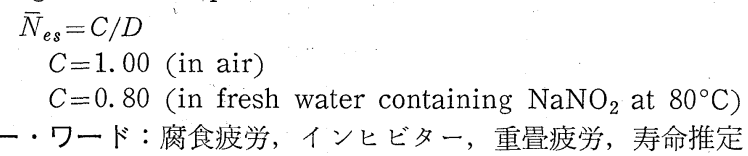

\section{1 まえがき}

舶用ディーゼル機関燃焼室構成部材には，機関の発 停によって生ずる熱応力（低周波成分）とこれに重畕 した燃焼ガス圧の繰返しに伴う機珹的応力（高周波成 分）が作用する. このような重畳波形疲労条件下では, 単一波形疲労条件下で見られるような疲労限度は存在 しないと言われている.ディーゼル機関のシリンダカ バーでは, 冷却面での腐食生成物付着による冷却効率 の低下や腐食疲労損傷を防止するため, 冷却水中へ亜 硝酸塩系インヒビター添加が行われている. しかし ながら, 重畳疲労条件下に抢汀亜硝酸塩系インヒビ ターの防食効果やインヒビター添加溶液中に特ける部 材の疲労寿命については, 実用上非常に重要であるに もかかわらず，未だ研究により明確にされていない。

そこで本研究では, 実機シリンダカバーの肉厚に近 い直径を有する比較的大型の丸棒試験片を用いて重冨 疲労試験を実施し, 重畺疲労寿命について検討した。
さらに亜硝酸塩系インヒビターを添加した溶液中にお 汁る重畳疲労試験から，その疲労寿命とインヒビター による腐食疲労防止効果について検討したので, その 結果について報告する.

$$
2 \text { 実 験 方 法 }
$$

\section{$2 \cdot 1$ 供試材}

供試材はディーゼル機関の燃焼室壁部材に広く用い られている Cr-Mo 鋳鋼で, $1050^{\circ} \mathrm{C} ， 2$ 時間保持油 焼入後, $690^{\circ} \mathrm{C}, 2$ 時間焼もどしの熱処理を施した. 供試材の化学組成之機械的性質を Table I, II 飞示 与.

Table I. Chemical composition of specimen (wt \%).

\begin{tabular}{c|c|c|c|c|c|c}
\hline $\mathrm{C}$ & $\mathrm{Si}$ & $\mathrm{Mn}$ & $\mathrm{P}$ & $\mathrm{S}$ & $\mathrm{Cr}$ & $\mathrm{Mo}$ \\
\hline 0.17 & 0.54 & 0.81 & 0.012 & 0.008 & 0.72 & 0.38 \\
\hline
\end{tabular}

†原稿受理 昭和59年10月 9 日 Received Oct. 9，1984

* 正会員 三井造船(株)玉野研究所 玉野市玉原, Tamano Laboratory, Mitsui Engineering and Shipbuilding Co. Ltd., Tamahara, Tamano

** 正会員 三井造船(株)ディーゼル事業部 玉野市玉, Diesel Engine Department, Mitsui Engineering and Shipbuilding Co. Ltd., Tama, Tamano 
Table II. Mechanical properties of specimen.

\begin{tabular}{c|c|c|c|c|c}
\hline $\begin{array}{l}\text { Yield } \\
\text { stress } \\
(\mathrm{MPa})\end{array}$ & $\begin{array}{c}\text { Tensile } \\
\text { strength } \\
(\mathrm{MPa})\end{array}$ & $\begin{array}{c}\text { True } \\
\text { strength } \\
(\mathrm{MPa})\end{array}$ & $\begin{array}{c}\text { Elonga- } \\
\text { tion } \\
(\%)\end{array}$ & $\begin{array}{c}\text { Reduction } \\
\text { of area } \\
(\%)\end{array}$ & $\begin{array}{c}\text { Brinell } \\
\text { hardness }\end{array}$ \\
\hline 471 & 618 & 1059 & 25 & 60 & 187 \\
\hline
\end{tabular}

\section{$2 \cdot 2$ 試験方法}

疲労試験片は試験部の径が $\phi 50 \mathrm{~mm}$ の砂時計型試 験片で, 試験片形状, 疲労試験機および腐食水々腐食 水循環系は前報と同じである.今回用いた応力波形を Fig. 1 亿示す. Fig. 1 (a), (b)は完全両振り（最大応力 飞対する最小応力の比 $R=-1)$ 打よび完全片振り $(R$ ０）正弦波の単独波で，繰返し速度は $600 \mathrm{cpm}$ であ る. Fig. 1 (c) は熱応力に相当与る両振台形波を 1 次波 とし，ガス圧応力に相当する正弦波を 2 次波とする重 疊波である. 1 次波応力の上昇時間 $T_{U}$ 劧上び下降時 間 $T_{D}$ はともに 20 秒, 压縮側の保持時間 $T_{o}$ は 30 秒 で, 2 次波の重盢山数 $n$ は, $n=10^{4}$ cycles, 繰返乙速 度は $600 \mathrm{cpm}$ である。

(a)

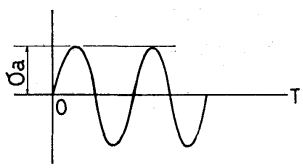

(b)

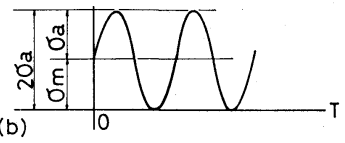

(c)

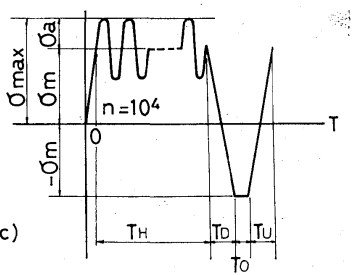

(a) Completely reversed sine wave.

(b) Zero-tension sine wave.

(c) Superposed wave.

Fig. 1. Stress wave.

1 次波応力振幅 $\sigma_{a 1}$ 之 2 次波応力振幅 $\sigma_{a 2}$ との和 を最大応力振幅 $\sigma_{\max }\left(=\sigma_{a 1}+\sigma_{a 2}\right)$, 最大応力 振 幅 $\sigma_{\max }$ に対する 2 次波応力振幅 $\sigma_{a 2}$ の割合を応力比 $m$ $\left(=\sigma_{a 2} / \sigma_{\max }\right)$ と定義する. 重畳疲労試験では, 最大 応力振幅 $\sigma_{\max }=588,549,510,471,432 \mathrm{MPa}$ 亿対 して, 応力比 $m=0.5,0.4,0.3$ を組又合せた. 疲労 試験は，大気中抒よび覀硝酸塩系インヒビター（以下， $\mathrm{NaNO}_{2}$ と記す） $3000 \mathrm{ppm}$ 添加した $80^{\circ} \mathrm{C}$, ASTM 腐食水中で実施した。

\section{3 疲労寿命推定法}

今回用いた疲労寿命推定法は等価繰返し数法（以下，
ELF 法と記す) とレンジ・ペア・ミーン法（以下， RPM 法と記す) である. 疲労寿命推定法については 既に多くの文献があるので，ここではその主要な点の みを記した。

疲労寿命推定に際して一定応力振幅完全両振り（R $=-1) S-N$ 線図を基準とし， $S-N$ 線図は式(1)のよう に表される.

$$
\begin{aligned}
N_{f} & \cdot \sigma_{a}^{a(f)}=K(f) \\
N_{f} & : \text { 破断繰返し数 } \\
\sigma_{a} & : \text { 応力振幅 } \\
a(f), K(f) & : \text { 実験定数 }
\end{aligned}
$$

$S-N$ 線戝は疲労限度以下まで直線を延長 して疲労限 度以下の応力を評価し（修正マイナー則），疲労損傷 $D$ を計算する．推定疲労寿命 $\bar{N}_{e s}$ は式(2)で表される.

$$
\bar{N}_{e s}=C / D, C: \text { Const }(=1.00)
$$

な持レンジ・ペア・ミーン法に怙ける平均応力の効果 は, 修正グッドマンの方法に拈いて引張強度 $\sigma_{B}$ の代 り飞真破断力 $\sigma_{T}$ を用いた方法 (以下, RPM 法 I と記す）特よび山田の方法 (以下， RPM 法 II と記す) により両振応力振幅 $\sigma_{t}$ 飞換算する. 換算式は次式の と抢りである。

$$
\begin{gathered}
\frac{\text { 修正グッドマンの方法 }}{\sigma_{t}=\sigma_{a} /\left(1-\sigma_{m} / \sigma_{T}\right)} \\
\sigma_{T}: \text { 真破断力 } \\
\frac{\text { 山田の方法 }}{\sigma_{t}=\sigma_{a}+q \sigma_{a}^{\gamma} \cdot \sigma_{m}} \\
q, r: \text { 実験定数 } \\
q=0.4, \quad r=0 \text { とすると } \\
\sigma_{t}=\sigma_{a}+0.4 \sigma_{m} \\
4 \text { 実験結果および考察 }
\end{gathered}
$$

\section{$4 \cdot 1$ 疲労試験結果}

大気中抒よび $\mathrm{NaNO}_{2}$ 添加 $80^{\circ} \mathrm{C}$, ASTM 腐食水中 に拈ける両振り $(R=-1)$ と片振り $(R \simeq 0)$ の $S-N$ 線図を Fig. 2 と示す。 $\mathrm{NaNO}_{2}$ 添加 $80^{\circ} \mathrm{C}$, ASTM 腐

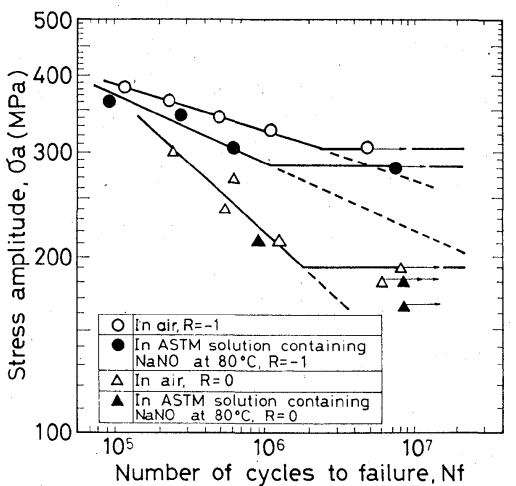

Fig. 2. Fatigue data of completely reversed and zero-tension stress for $\mathrm{Cr}-\mathrm{Mo}$ cast steel in air and in ASTM solution containing $\mathrm{NaNO}_{2}$ at $80^{\circ} \mathrm{C}$. 
食水中に和ける疲労強度は，大気中よりわずかではあ るが低下する。しかし一定応力振幅条件では疲労限度 $\sigma_{w}$ が存在する. 応力振幅 $\sigma_{a}$ 之破断繰返し数 $N_{f}$ 之 は対数的に直線関係が認められ，次式のように表すこ とができる。

大気中, 両振り $(R=-1)$

$$
\begin{gathered}
N_{f} \cdot \sigma_{a}{ }^{13.55}=1.17 \times 10^{40} \\
\sigma_{w} \simeq 304 \mathrm{MPa}
\end{gathered}
$$

片振り $(R \simeq 0)$

$$
\begin{gathered}
N_{f} \cdot \sigma_{a}^{4.22}=8.28 \times 10^{15} \\
\sigma_{w} \simeq 191 \mathrm{MPa}
\end{gathered}
$$

$\mathrm{NaNO}_{2}$ 添加 $80^{\circ} \mathrm{C}, \mathrm{ASTM}$ 腐食水中, 両振り $(R=$ $-1)$

片振り $(R \simeq 0)$

$$
\begin{gathered}
N_{f} \cdot \sigma_{a}^{8.75}=3.45 \times 10^{27} \\
\sigma_{w} \simeq 284 \mathrm{MPa}
\end{gathered}
$$

$$
\sigma_{w} \simeq 181 \mathrm{MPa}
$$

重畺疲労試験結果については, 2 次波の応力振幅 $\sigma_{a}$ と 2 次波の破断繰返し数 $N_{f}$ との関係を応力比 $m$ をパ ラメータとして整理した. Fig. 3，4 は大気中抽よ゙ $\mathrm{NaNO}_{2}$ 添加 $80^{\circ} \mathrm{C}$, ASTM 腐食水中に和壮る応力比

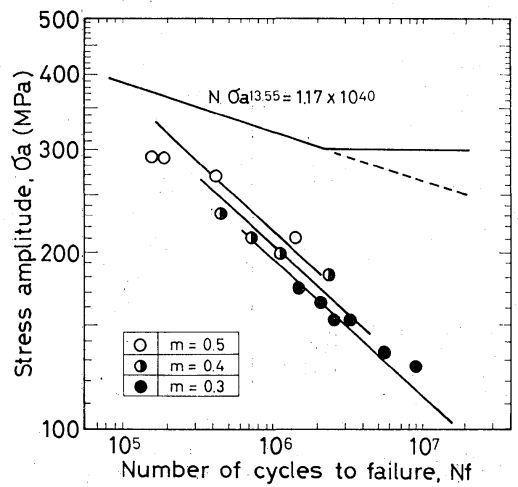

Fig. 3. Superposed fatigue data for $\mathrm{Cr}-\mathrm{Mo}$ cast steel in air.

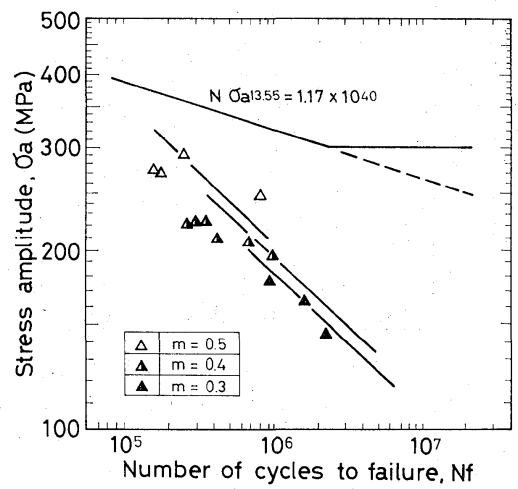

Fig. 4. Superposed fatigue data for $\mathrm{Cr}-\mathrm{Mo}$ cast steel in ASTM solution containing $\mathrm{NaNO}_{2}$ at $80^{\circ} \mathrm{C}$. $m=0.5,0.4,0.3$ の重畳疲労試験結果である. Fig. 3，4によれば，重畳疲労強度と破断繰返乙数との間 には, 応力比 $m=0.5,0.4,0.3$ に対して対数的な直 線関係が認められる. $\mathrm{NaNO}_{2}$ 添加 $80^{\circ} \mathrm{C}$, ASTM 腐 食水中の疲労強度は大気中に比べ若干低くなっている が, 疲労強度に特に大きな低下はなく, 塑性変形を伴 った重畳疲労条件下に扣いても $\mathrm{NaNO}_{2}$ による腐食疲 労防止効果が認められる. $\mathrm{NaNO}_{2}$ による鋼の防食過 程について H. H. Uhlig.らが述べているように, $\mathrm{NO}_{2}^{-}$イオンと溶存酸素との吸着層の形成と, これに つら゙く不働態皮膜の形成によるものであると報告した. 妨害イオンと $\mathrm{NO}_{2}{ }^{-}$イオン, 溶存酸素との競合吸着か ら, 局部的にも妨害イオン濃度の増加を生じなければ 鋼の不働態化は安定であり, 試験片に塑性疲労損傷を 受けても $\mathrm{NO}_{2}{ }^{-}$イオンと溶存酸素の吸着によって不働 態化は維持されたものと考えられる。

\section{$4 \cdot 2$ 疲労寿命の評価}

大気中抢よび $\mathrm{NaNO}_{2}$ 添加 $80^{\circ} \mathrm{C}, \mathrm{ASTM}$ 腐食水中

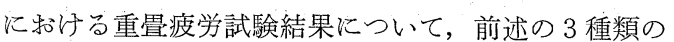
疲労寿命推定法を適用し，1 次波を基準とする推定寿 命 $\bar{N}_{e s}$ を算出した. 1 次波を基準とする重盢波形下の 実験寿命 $N$, 推定寿命 $\bar{N}_{e s}$ 抒よび実験寿命 $N$ と推定寿 命 $\bar{N}_{e s}$ との比 $N / \bar{N}_{e s}$ を Table III, IV に示す. ま た Fig. 5〜7 は大気中重畳疲労の実験寿命 $N$ と推定寿 命 $\bar{N}_{e s}$ との相関性を示すもので，寿命推定法はそれぞ れ ELF 法, RPM 法Iおよび RPM 法IIである. ELF 法 (Fig. 5) では, $1 / 2 \leqq N / \bar{N}_{e s} \leqq 7$ で比較的安 全側の寿命推定となるが，推定寿命 $\bar{N}_{e s} \geqq 10^{2}$ cycles の高寿命側で $N / \bar{N}_{e s}$ は低下する傾向が認められる. RPM 法 I (Fig. 6) では, $1 / 100 \leqq N / \bar{N}_{e s} \leqq 4$ である が, 寿命比 $N / \bar{N}_{e s}$ は広範囲に分散して和り, 特に高 寿命側の $\bar{N}_{e s}$ で危険側の寿命を推定する. RPM 法 II (Fig.7) では， $1 / 4 \leqq N / \bar{N}_{e s \leqq 5}$ で，全体としてほ涪 $N / \bar{N}_{e s}=1$ の近傍に分散している. $N / \bar{N}_{e s}$ の分散範囲 から今回適用した寿命推定法を比較すると, RPM 法 II の寿命推定の精度が最も高いことが分った。しかし， RPM 法II に扔いても ELF 法と同様, $\bar{N}_{e s} \geqq 10^{2}$ cycles の高寿命側で $N / \bar{N}_{e s}$ は低下し, 危険側の寿命を推定 する傾向にある. $N / \bar{N}_{e s}$ の低下原因の一つとして, 基 準 $S-N$ 線図のとり方が考えられる.

大気中の単独波疲労強度 (Fig. 2) と重畳疲労強度 (Fig. 3) を比較すると，片振り $(R \simeq 0)$ の時間強度は $m=0.5$ の重畳疲労強度に一致している. また $m=0.5$ の重疊疲労強度は $m=0.4,0.3$ の重冨疲労強度とほ

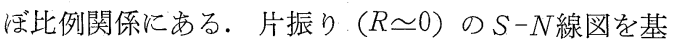
準として山田の方法を適用寸ると，負荷応力は次式の ように表すことができる。

$$
\sigma_{t}=\sigma_{a}+q \cdot\left(\sigma_{m}-\sigma_{a}\right), \quad q=0.2
$$


Table III. Results of fatigue test under superposed stress and fatigue life estimation (in air).

\begin{tabular}{|c|c|c|c|c|c|c|c|c|}
\hline \multirow{2}{*}{$\begin{array}{l}\text { Stress } \\
\\
\sigma_{\max } \\
(\mathrm{MPa})\end{array}$} & \multirow{2}{*}{$\begin{array}{l}\text { Stress } \\
\text { ratio } \\
\quad m\end{array}$} & \multirow{2}{*}{$\begin{array}{c}\text { Experi- } \\
\text { mental } \\
\text { life } \\
N \\
\text { (cycles) }\end{array}$} & \multicolumn{2}{|c|}{ ELF method } & \multicolumn{2}{|c|}{ RPM method I } & \multicolumn{2}{|c|}{ RPM method II } \\
\hline & & & $\begin{array}{c}\bar{N}_{e s} \\
\text { (cycles) }\end{array}$ & $N / \bar{N}_{e s}$ & $\begin{array}{c}\bar{N}_{e s} \\
\text { (cycles) }\end{array}$ & $N / \bar{N}_{e s}$ & $\begin{array}{c}\bar{N}_{e s} \\
\text { (cycles) }\end{array}$ & $N / \bar{N}_{e s}$ \\
\hline 588 & 0.5 & 17.3 & 3.52 & 4.92 & 5.01 & 3.45 & 4.40 & 3.93 \\
\hline 588 & 0.5 & 19.9 & 3.52 & 5.66 & 5.01 & 3.97 & 4.40 & 4.52 \\
\hline 588 & 0.4 & 45.9 & 8.86 & 5.18 & 33.9 & 1.36 & 14.7 & 3. 12 \\
\hline 588 & 0.3 & 155.8 & 22.5 & 6.93 & 339.6 & 0.46 & 53.9 & 2.89 \\
\hline 549 & 0.5 & 41.5 & 8.95 & 4.64 & 18.0 & 2.31 & 11.2 & 3.70 \\
\hline 549 & 0.4 & 77.0 & 22.6 & 3.41 & 133.5 & 0.58 & 37.5 & 2.05 \\
\hline 549 & 0.3 & 215.0 & 57.3 & 3.75 & 1251.3 & 0.17 & 137.2 & 1.57 \\
\hline 549 & 0.3 & 365.6 & 57.3 & 6.38 & 1251.3 & 0.29 & 137.2 & 2.67 \\
\hline 510 & 0.4 & 113.9 & 61.5 & 1.85 & 554.7 & 0.21 & 102.3 & 1.11 \\
\hline 510 & 0.3 & 286.1 & 156.3 & 1.83 & 4618.2 & 0.06 & 374.3 & 0.76 \\
\hline 510 & 0.3 & 306.7 & 156.3 & 1.96 & 4618.2 & 0.07 & 374.3 & 0.82 \\
\hline 471 & 0.4 & 241.4 & 182.0 & 1.33 & 2454.8 & 0.10 & 302.5 & 0.80 \\
\hline 471 & 0.3 & 574.0 & 46.2 & 11.24 & 17422.2 & 0.03 & 1106.7 & 0.52 \\
\hline 432 & 0.5 & 138.8 & 234.7 & 0.59 & 1259.9 & 0.11 & 293.8 & 0.47 \\
\hline 432 & 0.3 & 931.7 & 1501.9 & 0.62 & 68923.4 & 0.01 & 3596.5 & 0.26 \\
\hline
\end{tabular}

Table IV. Results of fatigue test under superposed stress and fatigue life estimation

(in ASTM solution containing $\mathrm{NaNO}_{2}$ at $80^{\circ} \mathrm{C}$ ).

\begin{tabular}{|c|c|c|c|c|c|c|c|c|}
\hline \multirow{2}{*}{$\begin{array}{l}\text { Stress } \\
\sigma_{\max } \\
(\mathrm{MPa})\end{array}$} & \multirow{2}{*}{$\begin{array}{l}\text { Stress } \\
\text { ratio } \\
\qquad m\end{array}$} & \multirow{2}{*}{$\begin{array}{l}\text { Experi- } \\
\text { mental } \\
\text { life } \\
\quad N \\
\text { (cycles) }\end{array}$} & \multicolumn{2}{|c|}{ ELF method } & \multicolumn{2}{|c|}{ RPM method I } & \multicolumn{2}{|c|}{ RPM method II } \\
\hline & & & $\begin{array}{c}\bar{N}_{e s} \\
\text { (cycles) }\end{array}$ & $N / \bar{N}_{e s}$ & $\begin{array}{c}\bar{N}_{e s} \\
\text { (cycles) }\end{array}$ & $N / \bar{N}_{e s}$ & $\begin{array}{c}\bar{N}_{e s} \\
\text { (cycles) }\end{array}$ & $N / \bar{N}_{e s}$ \\
\hline 588 & 0.5 & 26.0 & 3.52 & 7.40 & 5.01 & 5.19 & 4.40 & 5.91 \\
\hline 588 & 0.5 & 38.3 & 3. 52 & 10.9 & 5.01 & 7.65 & $4 . \Delta 0$ & 8.70 \\
\hline 588 & 0.4 & 30.9 & 8.86 & 3.49 & 33.9 & 0.91 & 14.7 & 2.11 \\
\hline 588 & 0.4 & 30.9 & 8.86 & 3.49 & 33.9 & 0.91 & 14.7 & 2.10 \\
\hline 588 & 0.4 & 39.2 & 8.86 & 4.43 & 33.9 & 1.16 & 14.7 & 2.66 \\
\hline 588 & 0.3 & 94.0 & 22.5 & 4.18 & 339.6 & 0.28 & 53.9 & 1.75 \\
\hline 549 & 0.5 & 17.0 & 8.95 & 1.92 & 18.0 & 0.96 & 11.2 & 1.54 \\
\hline 549 & 0.5 & 19.6 & 8.95 & 2.19 & 18.0 & 1.09 & 11.2 . & 1.75 \\
\hline 549 & 0.4 & 45.5 & 22.6 & 2.02 & 133.5 & 0.34 & 37.5 & 1.21 \\
\hline 549 & 0.4 & 70.6 & 22.6 & 3.13 & 133.53 & 0.53 & 37.5 & 1.88 \\
\hline 549 & 0.3 & 171.1 & 57.3 & 2.99 & 1251.3 & 0.14 & 137.2 & 1.25 \\
\hline 510 & 0.5 & 85.0 & 24.4 & 3.48 & 68.7 & 1.24 & 30.6 & 2.78 \\
\hline 510 & 0.4 & 105.0 & 61.5 & 1.71 & 554.7 & 0.19 & 102.3 & 1.03 \\
\hline 510 & 0.3 & 228.0 & 156.3 & 1.46 & 4618.2 & 0.05 & 374.3 & 0.61 \\
\hline
\end{tabular}

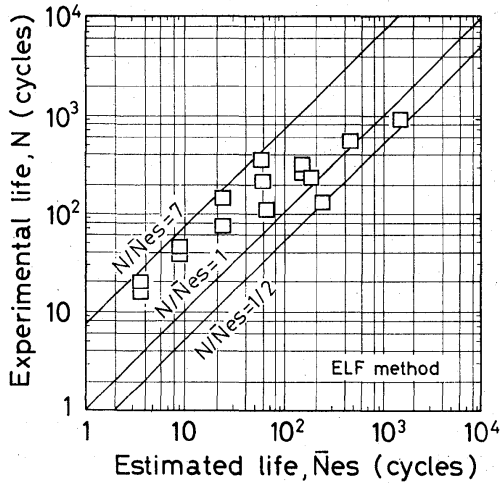

Fig. 5. Relation between estimated life $\bar{N}_{\text {es }}$ by ELF method and experimental life $N$ in air.

$$
\text { ただし } m \leqq 0.5
$$

RPM 法 II による低応力側での推定寿命を修正するた め, 両振り $(R=-1)$ 拉よび片振り $(R \simeq 0)$ の $S-N$ 線図を基準とし, 山田の方法により平均応力を評価し

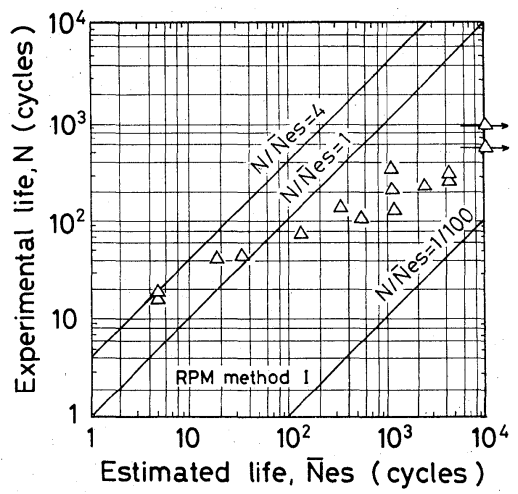

Fig. 6. Relation between estimated life $\bar{N}_{e s}$ by RPM method I and experimental life $N$ in air.

た. Fig. 8 は，実験寿命 $N$ と両振り $(R=-1)$ と片振

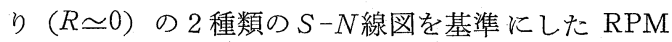
法 IIによる $\bar{N}_{e s}$ との相関性を示するのである. 両者の 


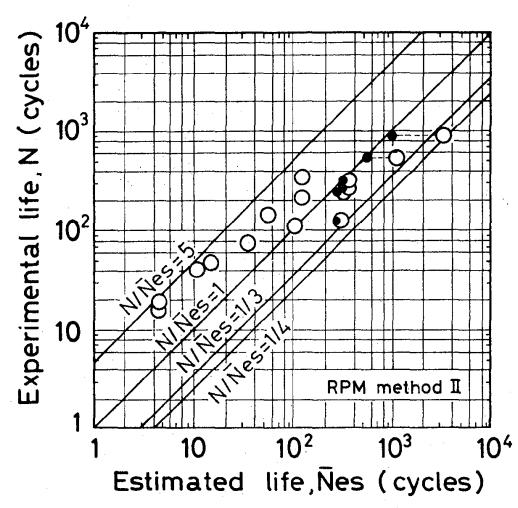

Fig. 7. Relation between estimated life $\bar{N}_{e s}$ by RPM method II and experimental life $N$ in air (• estimated life $\bar{N}_{e s}$ for the base of modified $S-N$ curve).

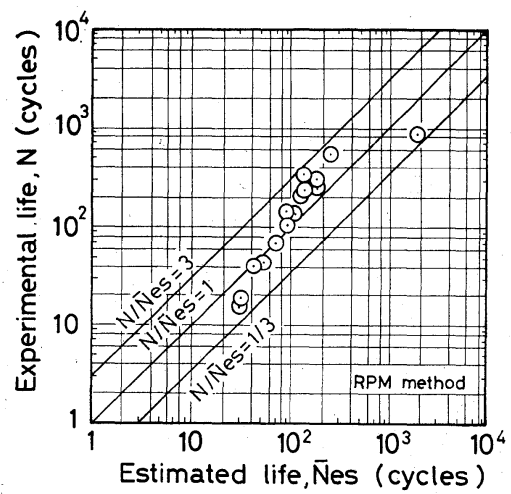

Fig. 8. Relation between estimated life $\vec{N}_{e s}$ by RPM method II and experimental life $N$ in air (the basis of completely reversed and zero-tension $S-N$ curve).

関係は疲労試験のばらつきの範囲内で一致し，非常に 良好な推定寿命の範囲を得ることができた．N/ $\bar{N}_{e s}$ は

$$
\frac{1}{3} \leqq N / \bar{N}_{e s} \leqq 3
$$

片振り（R乞0）の $S-N$ 線図を基準にした RPM 法 II が良好な寿命推定になった理由として，本実験に用い た重畳応力波形が重畳山数 $n=10^{4}$ の 2 重重疊応力波 形であり, また両振り $(R=-1)$ より片振り $(R \simeq 0)$ 飞近い応力波形であった. 平均応力の評価について理 論的な根拠が息しいため，片振り $(R \simeq 0)$ の $S-N$ 線 図を基準にした平均応力評価法が外插の程度は少なく 良好であったことなどが考觉られる。

前述の上らに両振 $(R=-1) S-N$ 線図を基準飞す ると, $\bar{N}_{e s}$ の増加とともに $N / \bar{N}_{e s}$ は低下し, $\bar{N}_{e s ~ \geqq 10^{2}}$ の高寿命側で危険側の寿命を推定することを示した. 両振 $(R=-1) S-N$ 線図を基準にするならば， $\bar{N}_{e s}$ $\geqq 10^{2}$ cycles に相当する疲労限度以下の $S-N$ 線図を Corten-Dolan 流飞補正する必要がある。 $N / \bar{N}_{e s}$ の結 果から両振 $(R=-1) S-N$ 線図を補正するため応力
振幅 $\sigma_{a}$ を $\sigma_{a}^{1 / 2}$ 亿置き換えると, 疲労限度以下の基 準 $S-N$ 線図は次式のように表される.

$$
N \cdot \sigma_{a}^{13.55 / 2}=1.77 \times 10^{13}\left(\sigma_{a} \leqq 304 \mathrm{MPa}\right) \text { (16) }
$$

補正 $S-N$ 線図を基準とし, 式(14), (11)を用いて 試験結 果の疲労寿命を算出し, $N$ と $\bar{N}_{e s}$ との相関性について 検討した. その結果をFig. 7 中に・印で示した. RPM 法 II の推定結果に比べ，本法の寿命推定による 結果は実験寿命 $N$ に近似され, 良好な推定寿命の範囲 を得ることができた。 $N / \bar{N}_{e s}$ は

$$
\frac{1}{3} \leqq N / \bar{N}_{e s} \leqq 5
$$

以上に述べた RPM 法 II を，実機ピストンクラウ ンの損傷事例に適用すると次のような結果が得られた. Fig. 9 は油冷却のシリンダ径 $42 \mathrm{~mm}$ の軸対称ピスト ンクラウン (42 VBF 型) で, 材質は $\mathrm{Cr}-\mathrm{Mo}$ 鋳鋼で ある. 就航後の定期点検から, Fig. 9 中A点で示した ピストンクラウンの一部にき裂が発見された。 き裂発 生時期は $3 \sim 10$ 年である. 運転実績の調查から, 機関 の発停頻度は約 50 時間に 1 回で, 年平均 2000 時間運 転していることが分った。また，機関の絽返し速度を $248 \mathrm{cpm}$ で, 重畳山数 $n$ は, $n=7.44 \times 10^{5}$ cycles であ る.

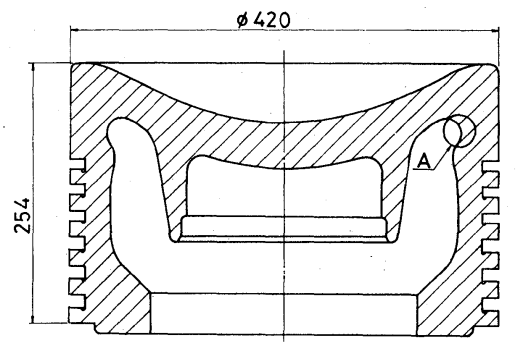

Fig. 9. Construction of piston crown (type 42 $\mathrm{VBF})$.

実機部材から疲労試験片（試験部径 $\phi 10 \mathrm{~mm}$ ) を切 り出して回転曲げ疲労試験を実施し，次のような結果 が得られた。

$$
N_{f} \sigma_{a}^{14.81}=2.46 \times 10^{42}, \quad \sigma_{w} \simeq 245 \mathrm{MPa}
$$

A 点での実機部材肉厚は $38 \mathrm{~mm} \sim 40 \mathrm{~mm}$, 機械加工 を施さず鋳肌のままである。才法効果, 鋳肌の影響に よる強度低下率 $\eta$ は,

$$
\eta=0.95 \times 0.80
$$

基準 $S-N$ 線図は次式の上らに表される.

$$
\begin{aligned}
& N \sigma_{a}{ }^{14.81}=4.23 \times 10^{40}, \quad \sigma_{a} \geqq \sigma_{w}=187 \mathrm{MPa} \quad(19) \\
& N \sigma_{a}^{14.81 / 2}=6.11 \times 10^{23}, \quad \sigma_{a}<\sigma_{w}=187 \mathrm{MPa} \quad(20) \\
& \text { ただし } R \leqq 0.5
\end{aligned}
$$

2 次元有限要素法に上る応力解析結果から, ピストン クラウンの A 点に怙ける機械的応力は - $76.6 \mathrm{MPa}$ で

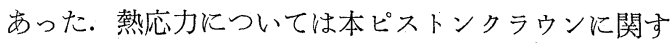
る詳細な温度分布値がなかったので, 同型機関のピス 
トンクラゥンから推定すると $279 \mathrm{MPa}$ になった。本 結果を用いて，1次波繰返し数に相当する機関の発停 回数 $\bar{N}_{e s}$ 孝算出すると次のようになる.

$$
\begin{aligned}
\bar{N}_{e s} & \simeq 154 \text { cycles } \\
& =7700 \mathrm{hr}(\simeq 4 \text { years })
\end{aligned}
$$

補正 $S-N$ 線図を基準とした RPM 法II による寿命推 定結果は，本機関に款けるピストンクラウンのき裂発 生時期と泳ぼ一致し, 本法は寿命推定法として有效で あると考觉られる。

つぎに, Fig. 10〜12 は $\mathrm{NaNO}_{2}$ 添加 $80^{\circ} \mathrm{C}, \mathrm{ASTM}$ 腐食水中重畳瘦労の実験寿命 $N$ と推定寿命 $\bar{N}_{e s}$ との相 関性を示すもので，寿命推定法はそれぞれELF 法, RPM 法 I 拈よび RPM 法 II である. 実験結果は低寿命 側に限られているが, ELF 法 (Fig. 10) では $1 \leqq N / \bar{N}_{e s}$ $\leqq 11$ で安全側の寿命を推定 し; RPM 法 I (Fig. 11) では $1 / 20 \leqq N / \bar{N}_{e s} \leqq 8$ で, 寿命比は広範囲洪分散し ている。 また大気中の結果と同様，高寿命側で $N / \bar{N}_{e s}$ の低下傾向が認められる，RPM 法II (Fig. 12) では $1 / 2 \leqq N / \bar{N}_{e s} \leqq 9$ となり，一部のデータを除政ば良好

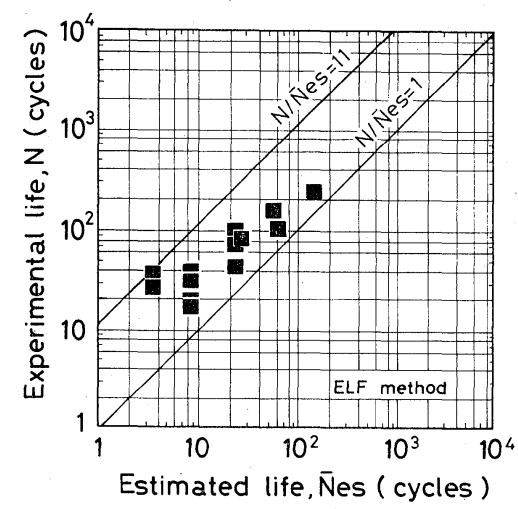

Fig. 10. Relation between estimated life $\bar{N}_{e s}$ by ELF method and experimental life $N$ in ASTM solution containing $\mathrm{NaNO}_{2}$ at $80^{\circ} \mathrm{C}$.

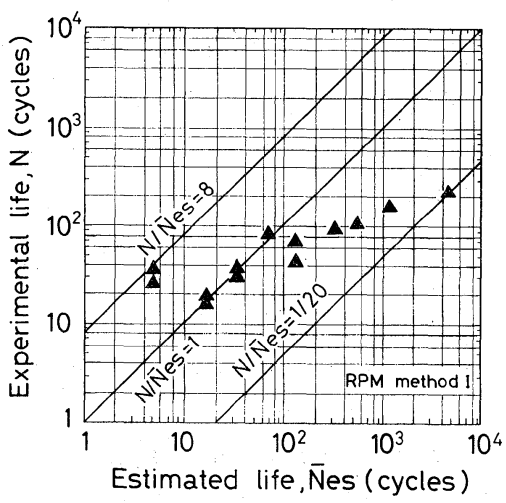

Fig. 11. Relation between estimated life $\bar{N}_{e s}$ by RPM method I and experimental life $N$ in ASTM solution containing $\mathrm{NaNO}_{2}$ at $80^{\circ} \mathrm{C}$.

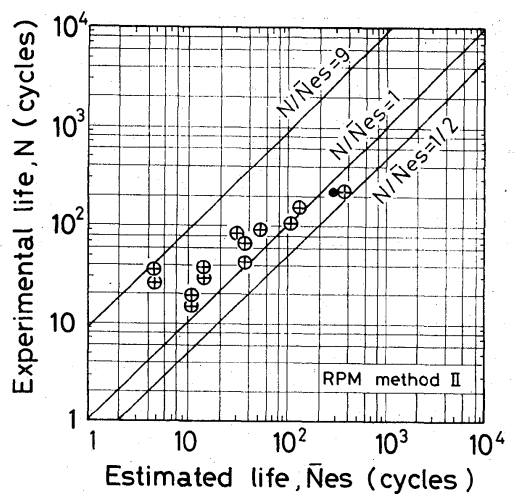

Fig. 12. Relation between estimated life $\bar{N}_{e s}$ by RPM method II and experimental life $N$ in ASTM solution containing $\mathrm{NaNO}_{2}$ at $80^{\circ} \mathrm{C}$ ( estimated life $\bar{N}_{e s}$ for the base of modified $S-N$ curve).

な結果を示している。な和補正 $S-N$ 線図を基準にし た RPM 法II の推定結果 $m=0.3, \sigma_{a}=153 \mathrm{MPa}$ を Fig. 12 中に・印で併記した.

Fig. 3，4 の重畳疲労試験結果を比較すると，NaN

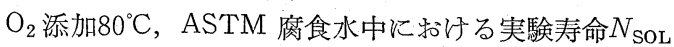
と大気中に数沙る実験寿命 $N_{\mathrm{AIR}}$ との比 $N_{\mathrm{SOL}} / N_{\mathrm{AIR}}$ は0.85〜0.80亿なる。大気中の結果によれば，高寿命 側で実験寿命 $N$ と推定寿命 $\bar{N}_{e s}$ が一致しているので, 高寿命側を含めた $\mathrm{NaNO}_{2}$ 添加 $80^{\circ} \mathrm{C}$, ASTM 腐食中 の寿命推定には，式(2)に示した定数 $C$ を補正する必要 が出る. 大気中疲労寿命推定に括いて，C=1.00 と乙 たが, 重畳疲労試験に特ける実験寿命比 $N_{\mathrm{SOL}} / N_{\mathrm{AIR}}$ から $C=0.80$ とする。

$$
\bar{N}_{e s}=\frac{0.80}{D}
$$

この值は中村らが実験的に求めたインヒビターによる 長期間の腐食疲労の影響を考慮した係数 $\eta_{3}$ 之汪涪一 致している.

\section{5 結言}

比較的大型の $\mathrm{Cr}-\mathrm{Mo}$ 鋳鋼試験片を用いて，大気中 特よび $\mathrm{NaNO}_{2}$ 添加 $80^{\circ} \mathrm{C}$, ASTM 腐食水中で重畳疲 労試験を実施し, 重畳疲労寿命について検討した，得 られた結果を要約すると次のと拉りである。

（1） ASTM 腐食水 $\left(\mathrm{NaNO}_{2}\right.$ 添加， $\left.80^{\circ} \mathrm{C}\right)$ 中の重畳 疲労強度は, 大気中のそれと比較すると若干低くなる が特に大きな疲学強度の低下はなく、 $\mathrm{NaNO}_{2}$ に上る 腐食疲労防止効果が認められる。

（2）今回用いた 3 種類の疲労寿命推定法 ELF 法, RPM 法 I 䦽よび RPM 法IIのうち， RPM 法IIが良 好な推定寿命を与克る. しかしいずれの寿命推定法に ついても，高寿命側で $N / \bar{N}_{e s}$ の低下傾向が認められ る. 疲労限度以下を補正した両振 $(R=-1) S-N$ 線 
図を基準にすると，高寿命側の実験寿命 $N$ は推定寿命 $\bar{N}_{e s}$ に近似し, 非常に良好な推定寿命が得られる.

$$
\frac{1}{3} \leqq N / \bar{N}_{e s} \leqq 5
$$

(3) $\mathrm{NaNO}_{2}$ 添加 $80^{\circ} \mathrm{C}, \mathrm{ASTM}$ 腐食水中に和忊る実 験寿命は大気中のそれより短くなるため, ASTM 腐 食水 $\left(\mathrm{NaNO}_{2}\right.$ 添加, $\left.80^{\circ} \mathrm{C}\right)$ 中では腐食疲労による影 響を考慮し, 定数 $C$ を補正する必要がある. 推定寿命 $\bar{N}_{e s}$ と累積損傷 $D$ との関係は次式のように表される。

$$
\begin{aligned}
N_{e s} & =C / D \\
C & =1.00 \text { (大気中) } \\
C & =0.80\left(\mathrm{NaNO}_{2} \text { 添加 } 80^{\circ} \mathrm{C}, \mathrm{ASTM}\right. \text { 腐食水中) }
\end{aligned}
$$

本研究の一部が日本造船研究協会第 164 研究部会の 研究として行われたことを付記し, 関係各位に謝意を 表します.

\section{参 考 文 献}

1）日本造船研究協会報告書，第83号，p. 4 (1976).

2）例觉ば，中村 宏，田中真一，“機械の㽻れ寿命算出法” 第VI章 (1972) 養賢堂.

3) 三浦健蔵, 熊田 誠, 大井利継, 材料, 34, 429 (1985).
4）中村 宏, 田中真一, 日本機械学会論文集， 32，1755 (1966).

5) 河本 実, 石川 浩, 尾上暉隆, 日本機械学会論文集, 37, 658 (1971).

6) 中村陽一, 中村 宏, 堀川 武, 材料, 30, 809 (1981).

7) 山田敏郎, 日本機械学会関西支部第49定時総会講演論文 集, p. 67 (1974).

8) H. H. Uhlig and S. Matsuda, J. Electrochem. Soc., 111, 156 (1964).

9) 三浦健蔵, 熊田 誠, 三宅良昭, 大井利継, 防食技術, 29, 85 (1980).

10) R. Nishimura, M. Araki and K. Kudo, CorrosionNACE, 40, 465 (1984).

11) 例觉ば, H.T. Corten, Proceeding of the Internation Conference on Fatigue of Metals, p. 235 (1956).

12）構造物の疲れ寿命推定法分科会報告書; p. 8 (1978) 日 本機械学会関西支部 $1 \mathrm{P}-\mathrm{SC} 22$ 分科会.

13）中村 宏, 恒成利康, 堀川 武, 機械の研究, 31, 1086 (1979).

14）“疲れ強さの設計資料 I ”, p.145 (1974) 日本機械学会.

15）“疲れ強さの設計資料II”, p. 4 (1974) 日本機械学会. 